\title{
Manajemen Kepemimpinan Kepala Sekolah Dalam Meningkatkan Kinerja Guru Pada SMP Al-Amanah Kecamatan Cileunyi Kabupaten Bandung
}

\author{
1)Ade Dasmana, 2)Nunung Kurniasih, 3)Ujang Cepi Barlian, 4)Sofyan Sauri \\ 1),2),3),4) Universitas Islam Nusantara Bandung \\ E-mail: adedasmanas327@gmail.com
}

\begin{tabular}{l}
\hline Article Info \\
\hline Article History \\
Received: $2020-11-17$ \\
Revised: 2021-01-05
\end{tabular}

Published: 2021-01-13

Keywords:

Leadership;

Headmaster;

Teacher performance.

\begin{abstract}
The success of an educational institution, in this case the school, is influenced by the principal's leadership in improving teacher performance. This study aims to determine the principal's policy program in improving teacher performance, the principal's leadership style in improving teacher performance, and the principal's barriers to improving teacher performance. This research uses descriptive qualitative, data collection techniques through observation, interviews, and study documentation with the research subjects are the principal, vice principal, and the teacher council. The results showed that: (1) The principal's policy program in improving teacher performance begins with deliberations between the principal and the vice principal and senior teachers in preparing school programs at the beginning of the new academic year, empowering teachers according to the abilities and wishes of the teacher, establishing work the same, complete infrastructure and be active in the Teacher Working Group (KKG); (2) The leadership style of the principal in fostering, guiding teachers by using instructive, consultative, participative, delegative styles in directing and influencing teachers to achieve educational goals; (3) The obstacles faced by the principal in improving teacher performance, the training program has not accommodated all types of disabilities that exist, the results of the training have not impacted the performance of teachers, there is still a lack of supporting facilities and infrastructure for learning.
\end{abstract}

\begin{tabular}{l}
\hline Artikel Info \\
\hline Sejarah Artikel \\
Diterima: 2020-11-17 \\
Direvisi: 2021-01-05 \\
Dipublikasi: 2021-01-13
\end{tabular}

Kata kunci:

Kepemimpinan; Kepala sekolah; Kinerja guru.

\begin{abstract}
Abstrak
Keberhasilan sebuah lembaga pendidikan dalam hal ini Sekolah dipengaruhi kepemimpinan kepala sekolah dalam meningkatkan kinerja guru. Penelitian ini bertujuan untuk mengetahui program kebijakan kepala sekolah dalam meningkatkan kinerja guru, gaya kepemimpinan kepala sekolah dalam meningkatkan kinerja guru, dan hambatan kepala sekolah dalam meningkatkan kinerja guru. Penelitian ini menggunakan deskriptif kualitatif, teknik pengumpulan data melalui observasi, wawancara, dan studi dokumentasi dengan subjek penelitian adalah kepala sekolah, wakil kepala sekolah, serta dewan guru. Hasil penelitian menunjukkan bahwa: (1) Program kebijakan kepala sekolah dalam meningkatkan kinerja guru diawali dengan musyawarah antara kepala sekolah dengan wakil kepala sekolah dan guru senior dalam menyusun program sekolah pada awal tahun ajaran baru, memperdayakan guru sesuai dengan kemampuan dan kemauan guru, menjalin kerja sama, melengkapi sarana prasarana serta aktif dalam Kelompok Kerja Guru (KKG); (2) Gaya kepemimpinan kepala sekolah dalam membina, membimbing guru dengan menggunakan gaya instruktif, konsultatif, partisipatif, delegatif dalam mengarahkan dan mempengaruhi guru untuk mencapai tujuan pendidikan; (3) Hambatan yang dihadapi kepala sekolah dalam meningkatkan kinerja guru, program pelatihan belum mengakomodir semua jenis ketunaan yang ada, hasil pelatihan belum mengimbas kepada kinerja guru- guru, masih kurang sarana dan prasarana pendukung pembelajaran.
\end{abstract}

\section{PENDAHULUAN}

Peran sumber daya manusia dalam sebuah organisasi merupakan sesuatu yang sangat penting. Tanpa sumber daya manusia, sebuah organisasi tidak akan berjalan dalam mencapai tujuannya. Sebuah organisasi dapat melaksanakan tata kelola manajemennya dengan sumber daya manusia yang berkualitas dalam menjalankan sebuah organisasi. Menurut (Barlian, 2016) bahwa setiap individu dituntut untuk memiliki pengetahuan yang memadai agar mampu mengikuti dan menyesuaikan diri terhadap setiap perubahan yang sedang dan akan 
terjadi di masa yang akan datang. Hal ini sejalan dengan Sastradipoera dalam (Suhardiman, 2012) bahwa sumber daya manusia bagi manajemen organisasi merupakan aktivitas yang sangat bernilai, krusial, dan rentan. Oleh karena itu, manajemen sumber daya manusia merupakan sesuatu yang fundamental bagi segenap kegiatan manajemen.

Sekolah merupakan sebuah lembaga yang memiliki peranan yang sangat penting dalam membangun sebuah generasi yang bermutu. Sehingga dalam mengelola Sekolah yang bermutu dibutuhkan peranan seorang pemimpin yakni kepala Sekolah dalam menyelenggarakan proses pendidikan yang berkualitas. Menurut (Sauri, 2016) mengemukakan bahwa pendidikan merupakan upaya yang terorganisir, berencana dan berlangsung kontinu (terus menerus sepanjang hayat) ke arah membina manusia/anak didik menjadi insan paripurna, dewasa dan berbudaya (civilized).

Kepala sekolah memiliki peran dalam sebuah proses pendidikan dalam rangka meningkatkan kinerja seorang pendidikan atau guru. Kepala sekolah memiliki tanggung jawab atas penyelenggaraan kegiatan pendidikan, administrasi sekolah, pembinaan tenaga lainnya, dan pendayagunaan serta pemeliharaan sarana dan prasarana sebuah lembaga pendidikan atau sekolah. Sebagai contoh kurang maksimalnya kepala sekolah dalam membina dan membimbing tenaga pendidik atau guru, sehingga masih ada tenaga pendidik atau guru yang masih memiliki karakter kurang disiplin dalam bertugas, terlambat datang dan pulang lebih awal. Hal seperti inilah yang menjadi permasalahan di lembaga pendidikan atau Sekolah.

Berdasar permasalahan-permasalah yang ada, maka yang menjadi tujuan penelitian ini yaitu: (1) Program kebijakan Kepala Sekolah dalam meningkatkan kinerja guru SMP Al-Amanah Kecamatan Cileunyi Kabupaten Bandung, (2) Gaya kepemimpinan Kepala Sekolah dalam meningkatkan kinerja guru pada SMP Al-Amanah Kecamatan Cileunyi Kabupaten Bandung, dan (3) Hambatan kepemimpinan Kepala Sekolah dalam meningkatkan kinerja guru pada SMP Al-Amanah Kecamatan Cileunyi Kabupaten Bandung.

Kepemimpinan memiliki peran sebagai penggerak dalam proses kerja sama antar manusia dalam sebuah organisasi termasuk lembaga pendidikan atau sekolah. Kepemimpinan memiliki fungsi dalam menghasilkan suatu organisasi bergerak secara terarah dalam upaya mencapai tujuan yang telah ditetapkan organisasi tersebut. Menurut (Usman, 2012) bahwa kepemimpinan mempengaruhi pemimpin untuk menggerakkan bawahannya menjadi taat, hormat, setia, dan mudah bekerja sama. Kepemimpinan merupakan inti dari manajemen, demikian halnya menurut (Sagala, 2013) bahwa kepemimpinan merupakan motor pengerak dari semua sumber-sumber dan alat-alat (resources) yang tersedia bagi suatu organisasi. Resources ini digolongkan dua bagian: (1) human resources; dan (2) non human resources.

Dalam mengklasifikasi fungsi sebuah kepemimpinan Menurut Covey dalam (Kaswan, 2013) bahwa ada empat peran kepemimpinan: Peran panutan, peran perintis, peran penyelaras, dan peran pemberdayaan. Pendapat yang sama menurut Robins dalam (Makawimbang, 2012) bahwa ada empat perilaku kepemimpinan yakni sebagai berikut:

1. Memerintah, pemimpin memberitahu apa dan kapan sesuatu dikerjakan, tidak ada partisipasi dalam pengambilan keputusan;

2. Mendukung, yaitu manajer menjadi sahabat bagi pegawai dan menunjukkan minat kepada mereka;

3. Memudahkan, yaitu pemimpin memberi saran dan melibatkan pegawai dalam pengambilan keputusan;

4. Orientasi Prestasi, yaitu pimpinan membagi kontribusi tentang tujuan dan menunjukan kepercayaan bahwa pegawai mampu mencapinya.

Dalam menjalakan fungsinya seorang pemimpin memiliki sebuah karakteristik dalam mengelola sebuah organisasi. Karakteristik ini kita kenal sebagai sebuah gaya seseorang dalam memimpin sebuah organisasi. Pemimpin memiliki perbedaan yang satu dengan yang lainnya tergantung dari berbagai aspek yang ada pada dirinya diantaranya pendidikan, pengalaman dan karakter. Hal ini yang banyak mempengaruhi karakter seorang pemimpin dalam mengelola dan memimpin sebuah organisasi. Menurut (Karwati, 2013) bahwa gaya kepemimpinan adalah suatu pola perilaku yang konsisten yang ditujukan oleh pemimpin dan diketahui pihak lain ketika pemimpin berusaha mempengaruhi kegiatan-kegiatan orang lain.

Pemimpin memiliki peran penting dalam meningkatkan mutu pendidikan di lembaga pendidikan atau Sekolah yang dipimpinnya, maka pemimpin tersebut harus memiliki atribut atau syarat dalam dirinya dalam menjalankan tugas dan tanggung jawab yang diberikan dan bekerja sama dengan guru dan stafnya. Syarat-syarat yang harus dimiliki pemimpin pendidikan menurut (Makawimbang, 2012) antara lain: (a) Rendah hati dan sederhana; (b) Bersifat suka menolong; (c) Sabar dan memiliki kesetabilan emosi; (d) Percaya kepada diri sendiri; (e) Jujur, adil dan dapat dipercaya; (f) Keahlian dalam jabatan. Untuk mengatasi masalah itu sebaiknya wawasan pemimpin setingkat diatas bawahannya. Menurut (Harun, 2009) bahwa Kepala sekolah adalah seorang guru yang diberi tugas tambahan untuk memimpin suatu sekolah. Kepala sekolah juga disebut pemimpin pendidikan di sekolahnya, walaupun kedua istilah tersebut identik, namun mempuyai perbedaan antara satu dengan lainnya.

Adapun seorang pemimpin dalam hal ini seorang kepala sekolah harus memiliki kompetensi sesuai dengan Peraturan Menteri Pendidikan Nasional Nomor 13 Tahun 2007 tentang standar kepala 
sekolah/madrasah, yaitu (1) Kepribadian, (2) Manajerial, (3) Kewirausahaan, (4) Supervisi dan (5) Sosial. Menurut Suhardiman, (2012) Kompetensi kepala sekolah yaitu kompetensi kepribadian, kompetensi manajerial, kompetensi kewirausahaan, kompetensi supervisi, dan kompetensi sosial.

Tugas pokok kepala sekolah menurut (Priansa, 2014) bahwa terdiri dari pencipta komunitas pembelajar, leader, manajer, dan supervisor. Kepala sekolah sebagai pencipta komunitas pembelajaran merupakan manifestasi dari kompetensi keperibadian kepala sekolah, yang pada dasarnya merupakan seseorang yang memiliki semangat belajar dan mau membelajarkan seluruh anggota sekolah dalam rangka meningkatkan kinerja sekolah.

Tugas kepala sekolah menurut (Karwati, 2013) bahwa tugas pokok kepala sekolah terdiri dari: Pencipta komunitas pembelajar leader, manajer, dan supervisor. Tugas kepala sebagai liader merefleksikan tugasnya sebagai innovator, dan motivator. Sedangkan tugas sebagai manajer merefleksikan tugas sebagai administrator. Tugas sebagai Supervisor adalah melaksanakan supervisi, yaitu kegiatan professional dalam rangka meningkatkan kualitas sekolah dan komponenya secara keseluruhan.

Kinerja merupakan terjemahan yang dianggap paling sesuai dari istilah performance dalam terminologi bahasa. Kata kinerja ini sering diartikan sebagai sebuah unjuk kerja, pencapaian kerja, atau penampilan kerja, Kinerja yang baik dapat dipengaruhi oleh kemampuan dan motivasi. Menurut (Supardi, 2013) bahwa kinerja merupakan suatu kegiatan yang dilakukan untuk melaksanakan, menyelesaikan tugas dan tanggung jawab sesuai dengan harapan, dan tujuan yang ditetapkan. Peningkatan kinerja merupakan peningkatan profesi pendidik menurut (Usman, 2012) bahwa sebuah profesi itu merupakan jabatan yang sesuai dengan pengertian sebagai berikut: (1) Melayani masyarakat, merupakan karier yang akan dilaksanakan sepanjang hayat (tidak berganti-ganti pekerjaan), (2) memerlukan bidang ilmu dan keterampilan tertentu diluar jangkauan khalayak ramai (tidak setiap orang dapat melakukannya), (3) memerlukan pelatihan khusus dengan waktu yang panjang, (4) mempunyai komitmen dengan jabatan dan klien, dengan penekanan terhadap layanan yang akan diberikan, (5) mempuyai organisasi yang diatur oleh anggota profesi sendiri. Berdasarkan permasalahan-permasalahan di atas, maka penelitian ini bertujuan untuk mencari secara komprehensif permasalahan terkait Kepemimpinan Kepala Sekolah dalam Meningkatkan Kinerja Guru pada SMP Al Amanah Kecamatan Cileunyi Kabupaten Bandung.

\section{METODE PENELITIAN}

Penelitian ini berupaya mengumpulkan data dan informasi yang berkaitan dengan kepemimpinan kepala sekolah dengan menggunakan pendekatan kualitatif, peneliti memusatkan diri pada persoalanpersoalan aktual melalui pengumpulan data. Menurut
(Sugiyono, 2012) mengemukakan bahwa penelitian kualitatif memiliki wawasan yang luas dan mendalam tentang bidang pendidikan yang akan diteliti dan mampu menciptakan rapport kepada setiap orang yang ada pada situasi sosial yang akan diteliti".

Menurut (Sukmadinata, 2010) penelitian kualitatif (qualitative research) adalah suatu penelitian yang ditujukan untuk mendiskripsikan dan menganalisis fenomena, pristiwa, aktivitas sosial, sikap, kepercayaan, persefsi, pemikiran orang secara individual maupun kelompok, semua diskripsi mengarah pada penyimpulan.

Penelitian ini dilaksanakan pada SMP Al-Amanah Kecamatan Cileunyi Kabupaten Bandung sejak Oktober 2020. Subjek penelitian adalah kepala sekolah, dewan guru SMP Al Amanah Cileunyi Bandung. Pengumpulan data dilakukan dengan interview (wawancara), observasi (pengamatan), dan studi dokumenntasi.

\section{HASIL DAN PEMBAHASAN}

\section{A. Kebijakan Kepala Sekolah dalam Merumuskan Program Peningkatan Kinerja Guru Pada SMP Al-Amanah Kecamatan Cileunyi Kabupaten Bandung}

Kebijakan seorang pimpinan lembega pendidikan atau kepala sekolah di sebuah sekolah adalah sangat penting. Karena semua kebijakan kepala sekolah menjadi motor penggerak bagi segenap sumber daya sekolah yang tersedia, terutama para tenaga pendidikan atau guru-guru di sekolah. Kepala sekolah dianggap sebagai seorang profesional apabila kepala sekolah mampu menguasai dngan baik pekerjaannya dan melebihi personal lain yang ada di sekolah dalam mengelola manajemen Sekolah secara komprehensif. Kepala sekolah harus memiliki dan memahami bidang tugas yang ditekuni secara komprehensif dalam menjalankan semua perannya dalam mengelola lembaga pendidikan.

Berdasar pada hasil penelitian yang didapat maka disimpulkan bahwa banyak program kebijakan kepala sekolah dapat meningkatkan kinerja guru baik secara langsung maupun tidak langsung misalnya terkait dengan pengembangan profesional guru yang berhubungan dengan penilaian kinerja guru dan supervisi guru, maka kepala sekolah memberikan kesempatan kepada guru-guru untuk mengembangan kapasitasnya. Peraturan-peraturan yang dikeluarkan secara resmi oleh Dinas Pendidikan dan Yayasan kontekstualisasi penerapan berdasarkan kondisi sekolah dimana peraturan tersebut akan diberlakukan.

Perencanaan yang dilakukan oleh kepala sekolah secara konkrit dengan menentukan tujuan-tujuan sekolah sesuai dengan visi dan misi sekolah. Jabaran konkrit tersebut antara lain: (1) rapat awal tahun ajaran para guru, (2) pembagian 
tugas oleh wakil kepala sekolah, (3) pembuatan jadwal kegiatan disertai dengan surat keputusan (SK) dan (4) rapat koordinasi masing-masing bidang.

Pelaksanaan kebijakan Kepala Sekolah dalam merumuskan program peningkatan kinerja guru menjadi lebih kontekstual, diantaranya; kepala sekolah memotivasi guru membuat membuat rencana pembelajaran, kepala sekolah membentuk tim pengembang kurikulum, kepala sekolah mengoptimalkan MGMP, kepala sekolah menginstruksikan penggunaan media belajar bervariasi, inovasi dan kontektual, kepala sekolah menginstruksikan pemberian bimbingan belajar bagi Siswa yang belum tuntas, kepala sekolah melibatkan lembaga eksternal dan internal diantaranya komite dan biro pendidikan dalam pengembangan pendidikan, kepala sekolah memprogramkan pelatihan/in house training, Kepala sekolah juga harus menterjemahkan visi, misi dan tujuan sekolah melalui program pengembangan kualitas guru, kegiatan whorkshop, pelatihan, seminar, dan diskusi mata pelajaran guna membahas permasalahan dan solusi untuk semua pelajaran serta kepala sekolah meningkatkan program pembinaan pada siswa. Kepala sekolah harus memiliki program dalam meningkatkan kompetensi profesional guru sebagai tolak ukur keberhasilan guru menyiapkan administrasi pembelajaran berupa program tahunan, program semester, silabus, Rencana Pelaksanaan Pembelajaran (RPP), dan instrument penilaian.

Kepala sekolah memiliki prioritas terhadap pengembangan guru dan staf perlu dilakukan pada setiap sekolah untuk memastikan bahwa mereka tetap mempertahankan kualitas profesionalitasnya sesuai dengan program setiap sekolah. Program pengembangan guru tersebut memberikan penekanan pada pembentukan keterampilan profesional mereka guna memperbaiki layanan sekolah. Kepala sekolah dalam mencapai tujuan programnya dapat dilakukan dengan memberikan kesempatan guru dan staf dalam kegiatan-kegiatan penataran, seminar, workshop, pemagangan dan pendampingan yang dapat diselenggarakan oleh lembaga pemerintah dan non pemerintah. Selain itu, kepala sekolah dalam pelaksanaan program pengembangan guru dan staf berbasis sekolah dapat pula dilaksanakan melalui program-program yang direncanakan sendiri oleh sekolah dan atau melalui jaringan antar sekolah bekerja sama dalam pengembangan kompetensi guru.

Evaluasi dilakukan dengan menganalisa hasil penilaian kinerja guru hasil supervisi guru, penilaian antar teman, wawancara, dan penilaian dari atasan dalam hal ini biro pendidikan dan ketuan Yayasan. Evaluasi juga dilihat dari berhasil tidaknya program kebijakan yang digulirkan oleh kepala sekolah, dan hasil evalusi menjadi bahan pertimbangan, solusi serta perbaikan dalam menindak lanjuti kebijakan yang diambil oleh kepala sekolah dalam meningkatkan kinerja guru sesuai dengan visi misi sekolah. Tindak lanjut dengan memberikan pembinaan kepada guru, kepala sekolah menjadi teladan, kemudian merumuskan RTL kedepannya dalam program peningkatan kinerja guru.

B. Gaya-gaya kepemimpinan Kepala Sekolah dalam Meningkatkan kinerja Guru pada SMP Al-Amanah Kecamatan Cileunyi Kabupaten Bandung

Faktor lain yang sangat berperan dalam keberhasilan suatu organisasi atau dalam hal ini lembaga pendidikan adalah gaya kepemimpinan, hal ini merupakan sebuah karakteristik setiap manusia antara satu dengan yang lain berbeda baik pengalaman, pendidikan, kondisi, lingkungan, pribadi, dan lain sebagainya. Hasil penelitian terkait kepemimpinan sekolah ini memberikan hasil bahwa, gaya-gaya yang diterapkan dalam meningkatkan kinerja guru antara lain gaya konsulatif dalam hal ini peran kepala sekolah dalam memotivasi, mengarahkan, dan membimbing guru harus dikedepankan. Kepala sekolah dalam menerapkan gaya kepemimpinannya kepala sekolah berkaitan dengan karakter kepribadiannya, yaitu kepala sekolah bersifat tegas, jujur dan terbuka, kecuali pada hal-hal yang bersifat prinsipil, percaya diri dalam membina guru-guru, berani mengambil resiko, bertanggung jawab. Berdasar pada hasil wawancara dengan responden berkaitan gaya kepemimpinan kepala sekolah dalam peningkatan kinerja guru, maka kepala sekolah melakukan pengarahan melalui komunikasi dua arah dan penjelasan-penjelasan yang terarah tentang tugastugas yang perlu dilakukan. Kepala sekolah terus memberikan motivasi kepada guru atau tenaga pendidik untuk dapat melaksanakan setiap tugasnya dengan baik dengan kompetensi yang dimiliki.

Dalam gaya partisipatif seorang kepala sekolah dan guru turut andil dalam mengambil keputusan. Seorang kepala sekolah sangat menghargai usaha dan mengkomunikasikan beberapa hal yang berkaitan dengan tenaga pendidik atau guru, terutama terkait motivasi dan kreativitas guru serta mempromosikan guru menjadi kepala sekolah dalam rangka regenerasi kepemimpinan. Sedangkan gaya kepemimpinan instruktif atau telling berarti seorang kepala sekolah banyak berperan dalam mengarahkan tugas-tugas guru. Kepala sekolah merumuskan peranan-peranan guru dan memberikan instruksi kepada guru sehingga kepala sekolah melakukan pengawasan yang ketat agar tujuan program tercapai terutama dalam mencapai tujuan meningkatkan kompetensi seorang guru. Hal ini menjadi prioritas dalam peran seorang pimpinan dalam hal ini seorang kepala sekolah. 
Sehingga gaya kepemimpinan merupakan suatu cara yang dilakukan kepala sekolah atau pimpinan dalam meningkatkan kinerja guru, maka tidak ada satu gaya pun yang ideal melainkan harus disesuaikan dengan tingkat kemauan dan kemampuan guru-gurunya, sebab menjadi kendala apabila terjadi kemampuan guru tinggi tetapi kemauannya rendah oleh karena itu untuk meningkatkan kinerja guru perlu adanya kemampuan dan kemauan. Hal ini menjadi fungsi utama seorang kepala sekolah dalam memberikan dukungan moril pada setiap guru dalam meningkatkan kinerjanya.

C. Hambatan-hambatan yang dihadapi kepala sekolah dalam meningkatkan kinerja pada SMP Al-Amanah Kecamatan Cileunyi Kabupaten Bandung

Berdasar pada hasil wawancara maka dapat disimpulkan bahwa ada berbagai hambatan dalam peningkatan kinerja guru di SMP Al-Amanah Kecamatan Cileunyi Kabupaten Bandung, diantaranya:

1. Kurang maksimal guru dalam menguasai IT pembelajaran.

2. Motivasi guru dalam menciptakan proses pembelajaran yang inovatif, kreatif dan menyenangkan masih kurang.

3. Sering bergantinya guru ketika ada pendaftaran PNS sehingga harus merekrut guru baru.

4. Guru yang memiliki kualifikasi belum S1; dan

5. Semua guru tidak semuanya mengikuti pelatihan-pelatihan karena keterbatasan anggaran sekolah.

Secara umum bahwa hambatan dalam meningkatkan kinerja adalah terkait pelatihan yang diberikan tidak mencakup semua jenis kebutuhaan yang ada pada SMP Al-Amanah. Setiap pekerjaan yang berhubungan dengan banyak orang pasti memilki kendala dan hambatan. Setiap sekolah pasti berbeda kendala yang dihadapi karena berbeda lingkungannya, ada yang bersifat individual dan ada yang bersifat umum sehingga apabila permasalahannya kecil kepala sekolah langsung mengambil tindakan sedangkan apabila permasalahannya besar kepala sekolah dibantu biro dan ketua Yayasan, guru-guru, serta kerjasama dengan komite sekolah.

Adapun berbagai hambatan yang dihadapi kepala sekolah atau pimpinan dalam meningkatkan kinerja guru secara umum adalah masih lemahnya kemampuan tenaga pendidikan atau guru dalam mengembangkan kurikulum dan penguasaan IT pembelajaran yang bervariasi, kurang menguasai metode yang sesuai dengan materi yang diajarkan, kurangnya pandangan terhadap anak sebagai individu yang berbeda kebutuhan dalam memperoleh materi yang disampaikan.

\section{KESIMPULAN DAN SARAN}

\section{A. Simpulan}

Berdasarkan hasil penelitian yang dilakukan maka dapat disimpulkan bahwa : 1) Kepala SMP Al-Amanah Cileunyi Kabupaten Bandung menyusun program kebijakan peningkatkan kinerja guru, dilaksanakan dalam rapat kerja di sekolah pada awal tahun ajaran dengan melibatkan guru. Program kebijakan yang ditetapkan seperti kalender akademik sekolah, peraturan sekolah baik untuk Siswa dan guru serta karyawan, kegiatan pengembangan diri guru dan karyawan, dan program sekolah, 2) Gaya kepemimpinan kepala sekolah dalam meningkatkan kinerja guru pada SMP Al-Amanah Cileunyi Kabupaten Bandung, menerapkan Gaya kepemimpinan yang berimbang antara penekanan pada perilaku otokratis, dan prilaku demokratis. Gaya kepemimpinan situasional dilaksanakan dengan menyesuaikan pada situasi dan kondisi sekolah. Situasi dan kondisi tersebut antara lain meliputi tingkat kematangan guru dan staf, dan 3) Hambatan yang dialami kepala SMP Al-Amanah Cileunyi Kabupaten Bandung antara lain: Program pelatihan yang diselenggarakan baik pemerintah maupun non pemerintah belum mampu mengakomodir semua jenis kebutuhan guru dan karyawan, belum ada program pelatihan yang berkesinambungan, serta hasil pelatihan belum berdampak kepada peningkatan kinerja guru.

\section{B. Saran}

Adapun saran yang dapat disampaikan berdasarkan hasil penelitian ini, perlu adanya inovasi berbagai macam kegiatan yang diprogramkan sekolah agar kemampuan guru meningkat. dan ada motivasi dan reward yang membuat kinerja guru lebih baik. Selain itu seorang tenaga pendidik atau guru hendaknya meningkat kinerjanya sebagai akibat dari gaya kepemimpinan yang diterapkan disekolah tersebut. Pemerintah hendaknya memperhatikan fasilitas sekolah yang kurang baik maupun yang telah rusak hendaknya diprioritaskan untuk segera dipenuhi dalam rangka memenuhi standar yang ditentukan guna menghasilkan proses penyelengaraan pendidikan yang efektif. Hal ini sebagai upaya dalam meminimalisir kendala yang dihadapi oleh kepala sekolah atau pimpinan dalam menerapkan gaya atau pola kepemimpinan yang dijalankan untuk mengelola sebuah organisasi dalam hal ini sekolah. Sedangkan untuk peneliti lain disarankan untuk melakukan penelitian secara komprehensif terkait dengan pola atau gaya kepemimpinan kepala sekolah serta upaya yang dapat dilakukan dalam meningkatkan kinerja guru disekolah secara khusus pada daerah-daerah yang dianggap masih tertinggal dalam penyelenggaraan pendidikan. 


\section{DAFTAR RUJUKAN}

Barlian. (2016). Pengaruh Motivasi Dan Iklim Organisasi Terhadap Kinerja Pegawai Pada PT. Kesuma Jakarta. Jurnal Manajemen, Kepemimpinan Dan Supervisi Pendidikan., 1(2).

Harun. (2009). Manajemen Sumber Daya Pendidikan. Yogyakarta: Pena Persada.

Kaswan. (2013). Membangun Tim yang Efektif dan Berkinerja Tinggi Melalui Kepemimpinan. Bandung : Alfabeta.

Makawimbang. (2012). Kepemimpinan Pendidikan yang Bermutu. Bandung : Alfabeta.

Sagala. (2013). Administrasi Pendidikan Kontemporer. Bandung : Alfabeta.

Sauri, S. (2016). Strategi Pembangunan Bidang Pendidikan Untuk Mewujudkan Pendidikan Bermutu. Bandung: UPI.
Sugiyono. (2012). Metode penelitian pendidikan. Bandung: Alfabeta.

Suhardiman. (2012). Studi Pengembangan Kepala Sekolah: Konsep dan Aplikasi. Jakarta: Rineka Cipta.

Sukmadinata. (2010). Metode penenelitian pendidikan. Bandung: PT Remaja Rosdakarya.

Supardi. (2013). Kinerja Guru. Jakarta: PT. Rajagrafindo Persada.

Usman. (2012). Manajemen Peningkatan Mutu Kinerja Guru: Konsep, Teori dan Model. Bandung: Citapustaka Media Perintis. 